\title{
PERIODISASI PERKEMBANGAN USHUL FIQH
}

\section{Zulhamdi*}

\begin{abstract}
ABSTRAK
Sejak zaman Rasulullab saw., sababat, tabiin dan sesudabnya, pemikiran bukum Islam mengalami perkembangan. Namun demikian, corak atau metode pemikiran belum terbukukan dalam tulisan yang sistematis. Dengan kata lain, belum terbentuk sebagai suatu disiplin ilmu tersendiri. Penulis mencoba mengulas tuntas tentang sejarah perkembangan ushul fiqh mulai zaman Nabi hingga sampai ushul fiqih menjadi sebuah disiplin ilmu tersendiri. Penelitian ini menggunakan pendekatan kualitatif deskriptif, dengan penelaaban dokumen. Periodisasi perkembangan ushul fiqh di mulai sejak zaman Rasulullah SAW sumber bukum Islam hanya dua, yaitu Al-Quran dan Assunnah, semenjak masa sababat telah timbul persoalanpersoalan baru yang menuntut ketetapan hukumnya. Untuke itu para sahabat berijtihad, mencari ketetapan bukumnya. Selanjutnya pada masa tabi'in, tabi'it-tabi'in dan para imam mujtabid, di sekitar abad II dan III Hijriyah wilayah kekuasaan Islam telah menjadi semakin luas, sampai ke daerah-daerah yang dibuni oleb orang-orang yang bukan bangsa Arab atau tidak berbahasa Arab dan beragam pula situasi dan kondisinya serta adat istiadatnya Dengan semakin tersebarnya agama Islam di kalangan penduduk dari berbagai daerah tersebut, menjadikan semakin banyak persoalan-persoalan bukum yang timbul, yang tidak didapati ketetapan bukumnya dalam Alquran dan As-Sunnah. Untuk itu para ulama yang tinggal di berbagai daerah itu berijtihad mencari ketetapan bukumnya.
\end{abstract}

\section{Kata Kunci: Periodesasi, Fiqh, Ushul Fiqh}

\section{PENDAHULUAN}

Sebagaimana ilmu keagamaan lain dalam Islam, ilmu ushul fiqih tumbuh dan berkembang dengan tetap berpijak pada Al-Quran dan Sunnah, ushul fiqih tidak timbul dengan sendirinya, tetapi benih-benihnya sudah ada sejak zaman Rasulullah dan sahabat. Masalah utama yang menjadi bagian ushul fiqih, seperti ijtihad, qiyas, nasakh, dan takhsis sudah ada pada zaman Rasulullah sahabat. Dan di masa Rasulullah saw, umat

* Penulis adalah Dosen Hukum Islam IAIN Malikussaleh Lhokseumawe, Email: zoel_hamdi@yahoo.co.id 
Islam tidak memerlukan kaidah-kaidah tertentu dalam memahami hukumhukum syar'i, semua permasalahan dapat langsung merujuk kepada Rasulullah saw lewat penjelasan beliau mengenai Alquran, atau melalui sunnah beliau saw.

Pada masa tabi'in cara mengistinbath hukum semakin berkembang. Di antara mereka ada yang menempuh metode maslalah atau metode qiyas di samping berpegang pula pada fatwa sahabat sebelumnya. Pada masa tabi'in inilah mulai tampak perbedaan-perbedaan mengenai hukum sebagai konskuensi logis dari perbedaan metode yang digunakan oleh para ulama ketika itu. (Muhammad Abu Zahrah,Tth)

Corak perbedaan pemahaman lebih jelas lagi pada masa sesudah tabi'in atau pada masa Al- Aimmat Al- Mujtahidin. Sejalan dengan itu, kaidah-kaidah istinbath yang digunakan juga semakin jelas bentuknya. Abu Hanifah misalnya menempuh metode qiyas dan istihsan. Sementara Imam Malik berpegang pada amalan mereka lebih dapat dipercaya dari pada hadis ahad. (Muhammad Abu Zahrah, Tth)

Apa yang dikemukakan di atas menunjukkan bahwa sejak zaman Rasulullah saw., sahabat, tabi'in dan sesudahnya, pemikiran hukum Islam mengalami perkembangan. Namun demikian, corak atau metode pemikiran belum terbukukan dalam tulisan yang sistematis. Dengan kata lain, belum terbentuk sebagai suatu disiplin ilmu tersendiri.

Dalam penulisan makalah ini penulis mencoba mengulas tuntas tentang sejarah perkembangan ushul fiqh mulai zaman Nabi hingga sampai ushul fiqih menjadi sebuah disiplin ilmu tersendiri. Agar kita mengerti tentang sejarahnya dan dapat bermanfaat bagi semua orang khususnya umat Islam.

Dalam penelitian ini penulis menggunakan pendekatan penelitian kualitatif deskriptif. Kualitatif karena penelitian ini menggunakan metode kualitatif, penelaahan dokumen. Deskriptif dalam arti peneliti berusaha mendeskripsikan secara sistematis dan akurat terhadap suatu data-data dan dokumen yang ada. Jenis penelitian yang penulis gunakan adalah penelitian Kepustakaan (Library Research). dengan cara menelaah sejumlah artikel, buku-buku dan membuka web-web untuk memperoleh data, teori dan konsep yang berhubungan dengan pembahasan ini. Dengan menggunakan metode dan teknik pengumpulan data tersebut, kiranya dapat terkumpul seluruh data yang dibutuhkan untuk mendukung penulisan jurnal ini, dapat pula menemukan suatu kesimpulan yang objektif 


\section{PERIODISASI PERKEMBANGAN USHUL FIQH A. Ushul Fiqh Masa Rasulullah}

Ushul fiqh sebagai sebuah bidang keilmuan lahir terlebih kemudian dibandingkan ushul fiqh sebagai sebuah metode memecahkan hukum. Kalau ada yang bertanya: "Dahulu mana ushul fiqh dan fiqh?" tentu tidak mudah menjawabnya. Pertanyaan demikian sama dengan pertanyaan mengenai mana yang lebih dahulu: ayam atau telor.

Musthafa Said al-Khin memberikan argumentasi bahwa ushul fiqh ada sebelum fiqh. Alasanya adalah bahwa ushul fiqh merupakan pondasi, sedangkan fiqh bangun yang didirikan di atas pondasi. Karena itulah sudah barang tentu ushul fiqh ada mendahului fiqh (Muhammad Sa'id al-Khinn, 1994: 122-123) Kesimpulannya, tentu harus ada ushul fiqh sebelum adanya fiqh.

Jawaban demikian benar apabila ushul fiqh dilihat sebagai metode pengambilan hukum secara umum, bukan sebuah bidang ilmu yang khas. Ketika seorang sahabat, misalnya, dihadapkan terhadap persoalan hukum, lalu ia mencari ayat Alquran atau mencari jawaban dari Rasulullah, maka hal itu bisa dipandang sebagai metode memecahkan hukum. Ia sudah punya gagasan bahwa untuk memecahkan hukum harus dicari dari Alquran atau bertanya kepada Rasulullah. Akan tetapi, cara pemecahan demikian belum bisa dikatakan sebagai sebuah bidang ilmu. Pemecahan demikian adalah prototipe (bentuk dasar) ushul fiqh, yang masih perlu pengembangan lebih lanjut untuk disebut sebagai ilmu ushul figh.

Prototipe-prototipe ushul fiqh demikian tentu telah ditemukan pada masa hidup Rasulullah sendiri. Rasulullah dan para sahabat berijtihad dalam persoalan-persoalan yang tidak ada pemecahan wahyunya. Ijtihad tersebut masih dilakukan sahabat dalam bentuk sederhana, tanpa persyaratan rumit seperti yang dirumuskan para ulama dikemudian hari Contoh ijtihad yang dilakukan oleh sahabat adalah ketika dua orang sahabat bepergian, kemudian tibalah waktu shalat.

Sayangnya mereka tidak punya air untuk wudhu. Keduanya lalu bertayammum dengan debu yang suci dan melaksanakan shalat. Kemudian mereka menemukan air pada waktu shalat belum habis. Salah satu mengulang shalat sedangkan yang lain tidak. Keduanya lalu mendatangi Rasulullah dan menceritakan kejadian tersebut. Kepada yang tidak mengulang Rasulullah bersabda: "Engkau telah memenuhi sunnah dan shalatmu mencukupi." Kepada orang yang berwudhu dan mengulang shalatnya, Rasulullah menyatakan: "Bagimu dua pahala." (Kisah di atas berasal dari hadits yang diriwayatkan oleh Imam Abu Dawud dan al-Nasa'i dari Abu Sa'id al-Khudri) 
Dalam kisah di atas, sahabat melakukan ijtihad dalam memecahkan persoalan ketika menemukan air setelah shalat selesai dikerjakan dengan tayammum. Mereka berbeda dalam menyikapi persoalan demikian, ada yang mengulang shalat dengan wudhu dan ada yang tidak. Akhirnya, Rasulullah membenarkan dua macam hasil ijtihad dua sahabat tersebut. Tidak hanya prototipe ijtihad, prototipe qiyas pun sudah ada pada masa Rasulullah. Kisah berikut menjadi contoh bagaimana qiyas dilakukan oleh Rasulullah.

Suatu saat seorang perempuan datang kepada Rasulullah dan mengatakan bahwa ibunya meninggal dunia dengan meninggalkan hutang puasa satu bulan. Rasulullah pun kemudian berkata yang artinya :

"Bagaimana seandainya ibumu memiliki butang, apakah engkau membayarkannya?" Perempuan tersebut menjawab: "Ya." Rasulullah berkata: "Hutang kepada Allah lebih berbak untuk ditunaikan." (H.R. al-Bayhaqi dari Ibnu Abbas, Hadits dengan makna yang sama diriwayatkan oleh Muslim)

Terhadap pertanyaan perempuan yang datang kepadanya, Rasulullah tidak menjawab dengan jawaban "Ya" atau "Tidak". Beliau menjawabnya dengan meng-qiyas-kan terhadap hutang piutang. Jadi, hukum hutang puasa orang tua yang meninggal dunia disamakan dengan hukum hutang piutang harta. Kasus tersebut menjadi bentuk dasar qiyas, yang dikemudian hari disusun prosedurnya secara baku oleh Imam Syafi'i.

Berbagai konsep ushul fiqh dapat ditemukan penggunaannya pada masa Rasulullah. Semua itu belum menjadi konsep baku, melainkan hanya sebagai buah dari pemecahan masalah praktis. Sama halnya seperti ketika orang Nusantara mempergunakan bahasa Melayu pada abad XVII atau XVIII. Mereka mengerti bagaimana mengucapkan bahasa Melayu yang benar berdasarkan kebiasaan dan pemahaman yang ada dalam otak mereka. Akan tetapi, kaidah-kaidah bahasa Melayu, yang kemudian disempurnakan menjadi kaidah bahasa Indonesia, baru ditulis dan dirumuskan belakangan dari praktek orang Melayu berbahasa.

\section{B. Ushul Fiqh Masa Sahabat}

Masa sahabat sebenarnya adalah masa transisi dari masa hidup dan adanya bimbingan Rasulullah kepada masa Rasulullah tidak lagi mendampingi umat Islam. Ketika Rasulullah masih hidup sahabat menggunakan tiga sumber penting dalam pemecahan hukum, yaitu Alquran, sunnah, dan ra'yu (nalar). Petunjuk paling jelas terhadap tiga sumber tersebut tampak dalam riwayat berikut:

Dari Muad₹: Bahwasanya Rasulullah SAW ketika mengutus Muadz ke Yaman, beliau bersabda: "Bagaimana kau memutuskan juga dibadapkan 
perkara kepadamu" Muadz, menjawab: "Saya putuskan dengan kitab Allah. Rasulullah bertanya kembali: "Jika tidak kau temukan dalam kitab Allah." Muad₹ menjawab: "Saya putuskan dengan sunnah Rasulullah SAW. Rasulullah bertanya: Jika tidak kan temukan dalam sunnah Rasulullab. Muadz menjawab: "Saya berijtibad dengan ra'yu saya dan tidak melampaui batas." Muadz lalu berkata: "Rasulullah memukulkan tangannya ke dada saya dan bersabda: "Segala puji bagi Allah yang telah memberikan petunjuk utusan Rasulullab terbadap apa yang diridloi Rasulullah." (Redaksi hadits di atas berasal dari Sunan al-Baihaqi. Riwayat yang hampir sama isi dan redaksinya juga dimuat dalam Musnad Ahmad bin Hanbal, Sunan Abu Dawud, dan Sunan Tirmidzi. Meskipun ada yang meragukan kesahihan hadits di atas, namun hadits tersebut sangat populer di kalangan ushuliyyin)

Meninggalnya Rasulullah memunculkan tantangan bagi para sahabat. Munculnya kasus-kasus baru menuntut sahabat untuk memecahkan hukum dengan kemampuan mereka atau dengan fasilitas khalifah. Sebagian sahabat sudah dikenal memiliki kelebihan di bidang hukum, di antaranya Ali bin Abi Thalib, Umar bin Khattab, Abdullah Ibnu Mas'ud, Abdullah Ibn Abbas, dan Abdullah bin Umar. Karir mereka berfatwa sebagian telah dimulai pada masa Rasulullah sendiri. (Thaha Jabir Alwani, $1994: 19$ )

Pada era sahabat ini digunakan beberapa cara baru untuk pemecahan hukum, di antaranya ijma' sahabat dan mashlahah. (Abdul Wahab Ibrahim Abu Sulaiman, 1983: 38-39) Pertama, khalifah (khulafa' rasyidun) biasa melakukan musyawarah untuk mencari kesepakatan bersama tentang persoalan hukum. Musyawarah tersebut diikuti oleh para sahabat yang ahli dalam bidang hukum. Keputusan musyawarah tersebut biasanya diikuti oleh para sahabat yang lain sehingga memunculkan kesepakatan sahabat. Itulah momentum lahirnya ijma' sahabat, yang dikemudian hari diakui oleh sebagian ulama, khususnya oleh Imam Ahmad bin Hanbal dan pengikutnya sebagai ijma yang paling bisa diterima.

Kedua, sahabat mempergunakan pertimbangan akal (ra'yu), yang berupa qiyas dan mashlahah. Penggunaan ra'yu (nalar) untuk mencari pemecahan hukum dengan qiyas dilakukan untuk menjawab kasus-kasus baru yang belum muncul pada masa Rasulullah. Qiyas dilakukan dengan mencarikan kasus-kasus baru contoh pemecahan hukum yang sama dan kemudian hukumnya disamakan. Penggunaan mashlahah juga menjadi bagian penting fiqh sahabat. Umar bin Khattab dikenal sebagai sahabat yang banyak memperkenalkan penggunaan pertimbangan mashlahah dalam pemecahan hukum. Hasil 
penggunaan pertimbangan mashlahah tersebut dapat dilihat dalam pengumpulan Alquran dalam satu mushaf, pengucapan talak tiga kali dalam satu majelis dipandang sebagai talak tiga, tidak memberlakukan hukuman potong tangan di waktu paceklik, penggunaan pajak tanah (kharaj), pemberhentian jatah zakat bagi muallaf, dan sebagainya. Sahabat juga memiliki pandangan berbeda dalam memahami apa yang dimaksud oleh Alquran dan sunnah. Contoh perbedaan pendapat tersebut antara lain dalam kasus pemahaman ayat iddah dalam surat al-Baqarah $228 .$. "Perempuan-perempuan yang ditalak hendaknya menunggu selama tiga quru"

Kata quru' dalam ayat di atas memiliki pengertian ganda (polisemi), yaitu suci dan haidh. Abu Bakar, Umar bin Khattab, Ali, Usman, dan Abu Musa al-Asy'ari mengartikan quru' dalam ayat di atas dengan pengertian haidh, sedangkan Aisyah, Zaid bin Tsabit, dan Ibnu Umar mengartikannya dengan suci. (Muhammad Sa ${ }^{6}$ id al-Khinn, 1994: 72) Itu berarti ada perbedaan mengenai persoalan lafal musytarak (polisemi). Secara umum, sebagaimana pada masa Rasulullah, ushul figh pada era sahabat masih belum menjadi bahan kajian ilmiah. Sahabat memang sering berbeda pandangan dan berargumentasi untuk mengkaji persoalan hukum. Akan tetapi, dialog semacam itu belum mengarah kepada pembentukan sebuah bidang kajian khusus tentang metodologi. Pertukaran pikiran yang dilakukan sahabat lebih bersifat praktis untuk menjawab permasalahan. Pembahasan hukum yang dilakukan sahabat masih terbatas kepada pemberian fatwa atas pertanyaan atau permasalahan yang muncul, belum sampai kepada perluasan kajian hukum Islam kepada masalah metodologi. (Muhammad al-Khudlary. Tth: 114)

Pada era tabi'in perbincangan mengenai persoalan ushul fiqh tidak banyak berbeda dengan era sahabat karena para tabiin adalah murid-murid para sahabat. Hal yang penting dicatat barangkali adalah bahwa pada era tabi'in, pembagian geografis mulai mendapatkan tempat dalam peta pemikiran hukum Islam. Perbincangan tersebut disertai dengan munculnya sentral-sentral pengembangan kajian hukum Islam di amshar (kota-kota besar Islam), seperti Makkah dan Madinah, Iraq (Kufah), Syiria, dan Mesir.

\section{Ushul Fiqh Masa Tabi'in}

Tabi'in adalah generasi setelah sahabat. Mereka bertemu dengan sahabat dan belajar kepada sahabat. Patut dicatat bahwa para sahabat ketika Islam menyebar turut pula menyebar ke berbagai daerah, seperti Ibnu Mas'ud ada di Iraq, Umayyah ada di Syam, Ibnu Abbas di Makkah, Umar bin Khattab, Aisyah, dan Ibnu Umar, dan Abu Hurairah di Madinah, dan Abdullah bin Amru bin Ash di Mesir. Para sahabat tersebut 
berperan dalam penyebaran ajaran Islam dan menjadi tempat masyarakat masing-masing daerah meminta fatwa. Mereka pun memiliki murid-murid di daerah-daerah tersebut. Murid-murid sahabat itulah yang kemudian menjadi tokoh hukum di daerahnya masing-masing. Murid-murid para sahabat tidak hanya dari kalangan orang-orang Arab, melainkan juga dari kalangan muslim non-Arab (mawali). Banyak pemberi fatwa yang terkenal di kalangan tabi'in adalah non-Arab, seperti Nafi, Ikrimah, Atha' bin Rabbah (para ahli hukum Makkah), Thawus (ahli hukum Yaman), Ibrahim al-Nakha'i (ahli hukum Kufah), Hasan al-Bashri dan Ibnu Sirin (para ahli hukum Bashrah), Yahya ibn Katsir. (Taha Jabir Alwani. 1994) (Lihat juga Muhammad al-Khudary, Tth: 150-162).

Kecenderungan berpikir sahabat turut mempengaruhi pola pemikiran ushul figh di masing-masing daerah. Ibnu Mas'ud, misalnya, dikenal sebagai tokoh yang memiliki kemampuan ra'yu yang baik. Tidak mengherankan apabila murid-muridnya di Iraq (Kufah) juga dikenal dengan ahl al-ra'yi, meskipun ada faktor lain yang tentunya berpengaruh. Karena itulah, metode istimbath tabi'in umumnya tidak berbeda dengan metode istimbath sahabat. Hanya saja pada masa tabi'in ini mulai muncul dua fenomena penting:

\section{Pemalsuan hadits}

Perdebatan mengenai penggunaan ra'yu yang memunculkan kelompok Iraq (ahl al-ra'yi) dan kelompok Madinah (ahl al-hadits) Dengan demikian muncul bibit-bibit perbedaan metodologis yang lebih jelas yang sertai dengan perbedaan kelompok ahli hukum (fukaha) berdasarkan wilayah geografis. Dua hal tersebut, ditambah munculnya para ahli hukum non-Arab, melahirkan wacana pemikiran hukum yang nantinya melahirkan madzhab-madzhab hukum Islam. Masing-masing madzhab hukum memiliki beberapa aspek metode yang khas, yang membedakannya dengan madzhab yang lain.

\section{Ushul Fiqh Masa Imam Madzhab}

Pada masa imam madzhab inilah pemikiran hukum Islam mengalami dinamika yang sangat kaya dan disertai dengan perumusan ushul fiqh secara metodologis. Artinya, ada kesadaran mengenai cara pemecahan hukum tertentu sebagai metode khas. Berbagai perdebatan mengenai sumber hukum dan kaidah hukum melahirkan berbagai ragam konsep ushul fiqh. Imam Najmuddin al-Thufi pada peralihan abad ke-7 ke abad ke-8 hijriyah, misalnya, menginventarisir sembilan belas dalil hukum, baik yang disepakati maupun yang dipertentangkan para ulama, yang masih dikenal pada masanya. Kesembilan belas dalil hukum itu antara lain: 1. Alquran 
2. Hadits

3. Ijma' ummat

4. Ijma' orang Madinah

5. Qiyas,

6. Pendapat sahabat

7. Mashlahah mursalah

8. Istishab

9. Bara'ah ashliyah

10. Adat/'urf

11. Istiqra' (induksi)

12. sadd al-dzariah (tindakan preventif)

13. Istidlal

14. Istihsan

15. Mengambil yang lebih mudah

16. Ishmah

17. Ijma' orang Kufah

18. Ijma' sepuluh orang, dan

19. Ijma khulafa' yang empat (khulafa' rasyidin) (Najmuddin al-Thufi, 1998: 237-238.)

Perdebatan mengenai dalil hukum, baik tentang sunnah, amal ahli Madinah, istihsan, qiyas, mashlahah mursalah, ijma', ra'yu, mencapai puncaknya. Imam Malik dan orang-orang Madinah sangat menghargai amal orang-orang Madinah. Ketika ada hadits Rasulullah diriwayatkan secara ahad (diriwayatkan oleh satu atau beberapa orang tapi tidak mencapai derajat pasti/mutawatir) bertentangan dengan amal ahli Madinah, amal ahli Madinah lah yang dipergunakan. Alasannya adalah bahwa amalan orang Madinah adalah peninggalan para sahabat yang hidup di Madinah dan mendapatkan petunjuk dari Rasulullah. Amalan orang Madinah telah dilakukan oleh banyak sekali sahabat yang tidak mungkin menyalahi ajaran Rasulullah, yang selama sepuluh tahun hidup di Madinah.

Oleh karena itu, Imam Malik pernah berkirim surat kepada Imam al-Laits, imam orang Mesir, yang isinya mengajak Imam laits untuk mempergunakan amalan orang Madinah. Akan tetapi tawaran tersebut ditolak oleh Imam Laits karena ia lebih setuju mengutamakan hadits, meskipun hadits itu ahad. Orang Iraq, khususnya Imam Abu Hanifah, mempergunakan istihsan apabila hasil qiyas, meskipun benar secara metode, dirasa tidak sesuai dengan nilai dasar hukum Islam. Penggunaan istihsan oleh Imam Abu Hanifah tersebut ditentang ulama lain dan dipandang sebagai pemecahan hukum berdasarkan hawa nafsu. Orangorang Iraq juga dikritik karena mempergunakan ra'yu secara berlebihan. Sementara itu, bagi orang Iraq, mempergunakan petunjuk umum ayat dan 
ra'yu lebih dirasa memadai dibandingkan mempergunakan riwayat dari Rasulullah, tetapi riwayat tersebut tidak meyakinkan kesahihannya.

Penggunaan amal Madinah oleh Imam Malik dan istihsan oleh Imam Abu Hanifah tidak berarti keduanya mengabaikan hadits. Alquran dan hadits tetap menjadi pilar utama istimbath hukum. Imam Malik adalah orang pertama yang menyusun kitab hadits, yaitu dalam kitabnya alMuwaththa'. Kitab al-Muwaththa' adalah kitab hadits yang dipergunakan sebagai dasar pemecahan masalah hukum sehingga disusun dengan sistematika fiqh. Imam Abu Hanifah dan para muridnya juga sangat menghargai hadits. Hasil istimbath hukum Imam Abu Hanifah dan orangorang Iraq juga dipenuhi dengan dasar Alquran dan hadits. Penolakan terhadap hadits tertentu terjadi karena keduanya mengutamakan riwayat yang kuat. Bagi Imam Malik, amalan orang Madinah sangat kuat karena diamalkan ribuan sahabat sejak masa Nabi Muhammad. Jadi, amalan orang Madinah tidak bisa dikalahkan hanya oleh riwayat oleh satu dua orang saja. Apabila riwayat tersebut bisa dibuktikan secara meyakinkan tentu Imam Malik akan menerimanya. Hal yang sama terjadi dengan Imam Abu Hanifah. Terjadinya pemalsuan hadits membuat orang-orang Iraq bertindak selektif. Apabila ada riwayat yang diragukan kesahihannya, mereka lebih merasa aman mempergunakan makna umum Alquran dan menjabarkannya melalui ra'yu (nalar) mereka. Akan tetapi, kalau ada hadits yang sahih tentu hadits tersebut yang dijadikan sandaran.

Sejalan dengan munculnya pemlsuan hadits tersebut, muncullah aliran ingkar al-sunnah. Aliran tersebut berpandangan bahwa Alquran saja sudah cukup dijadikan sebagai pedoman, tanpa perlu mempertimbangkan hadits. Aliarn tersebut adalah kelompok yang frustasi akibat terjadinya pemalsuan hadits sehingga menolak keseluruhan hadits, tanpa melalui penelitian terlebih dahulu. Memang pada masa tersebut Imam Bukhari, Imam Muslim dan para pengumpul hadits belum banyak seperti pada abad ke-4 Hijriyah, meskipun telah ada beberapa kitab hadits. Terhadap munculnya aliran ingkar al-sunnah tersebut, Imam Syafi'i bekerja keras membantah argumentasi kelompok ingkar al-sunnah. Perdebatan Imam Syafii dengan ingkar al-sunnah bisa dibaca dalam kitab al-Umm..

Imam Syafii kemudian mengajukan sistematika dalil hukum yang utama, yaitu:

1. Alquran

2. Sunnah

3. Ijma'

4. Qiyas

Melalui sistematika tersebut, Imam Syafi'i menegaskan kembali Alquran sebagai sumber pertama, sedangkan hadits sebagai sumber kedua. 
Dengan rumusan semacam itu, dia menolak pandangan ingkar al-sunnah dan juga menolak sikap sebagian ulama ushul yang mendahulukan amalan orang Madinah atau makna umum Alquran dibandingkan hadits ahad. Gagasan demikianlah yang kemudian melahirkan madhab Syafici.

Imam Syafi'i melakukan pendisiplinan dan sistematikasi penggunaan ijma dan qiyas para oleh pendahulunya. Ia mengkritik ijma' yang dilakukan berdasarkan kedaerahan, yaitu ijma' ahli Madinah dan ijma' orang Kufah. Beliau menegaskan bahwa ijma' yang valid adalah ijma' umat Islam, tidak cukup ijma' orang Kufah orang Madinah, atau ijma' sahabat saja. Imam Syafi'i juga membenahi penggunaan qiyas agar dilakukan secara metodologis. Beliau mengajukan syarat-syarat agar qiyas dilakukan, yaitu melalui empat rukun qiyas, yang akan dibahas dalam bab qiyas nanti.

Karya Imam Syafi'i, yaitu al-Risalah, adalah kitab ushul fiqh yang pertama ditulis. Kitab tersebut menjadi tonggak bagi perkembangan ushul fiqh sebagai bidang ilmu yang mandiri. Para ahli ushul menganggap Imam Syafi'i sebagai Bapak dan Pendiri ilmu ushul fiqh. (Abu Zahrah. Tth: 13). Lihat juga (Noel James Coulson,1964: 53)

Di kalangan madzhab Hanafi ada yang menolak bahwa Imam Syafi'i sebagai pendiri ushul fiqh. Mereka menyatakan bahwa Imam Abu Hanifah dan dua muridnya: Imam Abu Yusuf Ibnu Abi Laila dan Muhammad bin Hasan al-Syaybani adalah peletak ilmu ushul fiqh.( (Abu Zahrah. Tth: 13) Sejarah memang mencatat bahwa Imam Syafi'i pernah berguru kepada Imam Muhammad bin Hasan al-Syaybani. Klaim golongan Hanafi boleh jadi benar apabila dikaitkan dengan munculnya gagasan metodologis ushul fiqh. Imam Syafici tidak memulai segalanya dari ruang kosong. Rumusan-rumusan yang beliau tulis tentu telah dibicarakan orang pada masanya. Apalagi pemikiran ushul fiqh di Iraq memang kaya dan maju di masa itu. Hanya saja, Imam Syafíi lah yang memiliki bukti otentik, berupa karya, yang bisa menjadi patokan bagi dimulainya ushul fiqh sebagai bidang ilmu yang mandiri.

Setelah lahirnya kitab al-Risalah, perdebatan mengenai aspek metodologis masih terjadi dan perbedaan pendapat pun masih ada. Imam Ahmad bin Hanbal, meskipun murid Imam Syafi ${ }^{\circ}$, hanya menerima ijma sahabat, bukan ijma' ummat. Imam Dawud al-Dzahiri menolak penggunaan qiyas dan lebih condong untuk menggunakan makna universal lafal Alquran atau hadits untuk diberlakukan kepada kasus-kasus baru. 


\section{E. Tokoh-tokoh dan Karya-karya Besar Ushul Fiqh}

Puncak perkembangan ushul fiqh terjadi sekitar pada abad ke-5 Hijriyah. Pada masa tersebut, lahir para ulama dan karya-karya ushul fiqh kenamaan yang menjadi rujukan kitab-kitab ushul fiqh di kemudian hari. Di antara kitab-kitab penting ushul figh yang lahir pada abad ke-5 tersebut antara lain:

1. Kitab al-Ahd atau al-Amd karya Qadli Abd al-Jabbar al-Mu'tazili (w. $415 \mathrm{H} / 1024 \mathrm{M})$

2. Kitab al-Mu'tamad karya Abu Husayn al-Bashri al-Mu'tazili (w. $436 \mathrm{H}$ $1044 \mathrm{M})$

3. Kitab al-'Uddah karya Abu Ya'la al-Hanbali (w. 458H/1065M)

4. Kitab al-Ihkam fi 'Ushul al-Ahkam karya Ibnu Hazm al-Dzahiri (w. $456 \mathrm{H} / 1062 \mathrm{M})$

5. Kitab al-Luma' karya Abu Ishaq al-Syirazi al-Syafíi (w. 467H /1083 $\mathrm{M})$

6. Kitab al-Burhan karya Al-Juwayni al-Syafici (w. 478H /1085M)

7. Kitab Ushul Al-Sarakhsi karya Imam al-Sarakahsi al-Hanafi (w. 490H/1096M).

Imam Abu Hamid Al-Ghazali wafat pada tahun $505 \mathrm{H}$ atau abad ke-6, tetapi sebagian hidupnya dihabiskan pada abad ke k-5. Karena itu, kitab al-Mustashfa karya al-Ghazali dapat dimasukkan ke dalam jajaran kitab yang dilahirkan ulama abad ke-5.

Di antara kitab-kitab di atas, ada empat kitab yang kemudian memperoleh pengakuan sebagai kitab terbaik dan mempengaruhi perkembangan ushul fiqh selanjutnya di kalangan mutakallimin, yaitu alAhd karya Qadli Abdul Jabbar, al-Mu'tamad karya Abu Husayn al-Bashri, al-Burhan karya al-Juwayni, dan al-Musthasfa karya al-Ghazali. Kitab-kitab tersebut disebut Ibnu Khaldun sebagai kitab ushul fiqh terbaik. Empat kitab tersebut kemudian diringkas dan dijabarkan kembali oleh para ulama setelahnya, khususnya para ulama abad ke-7 Hijriyyah, seperti Fakhruddin al-Razi, al-Amidi, Ibnu Qudamah, Ibnu Hajib dan sebagainya.

Karena itu, muncullah beberapa kesepakatan dalam berbagai kitab ushul mengenai sistematikasi bahasan kitab ushul. Bahasan mengenai hukum, kaidah-kaidah-kaidah kebahasaan, kaidah naskh dan tarjih, dalil hukum, dan ijtihad hampir ada di semua kitab ushul fiqh mutakallimin yang berakar dari empat kitab di atas. Perbedaan bahasan terjadi dalam beberapa aspek, misalnya tentang pengantar logika, pembahasan kalam, dan tentang huruf, yang ada disebagian kitab ushul dan tidak ada disebagian kitab ushul yang lain. (Lihat Wael B. Hallaq, 1997: 127) 


\section{F. Aliran-Aliran Ushul Fiqh}

Sejarah perkembangan ushul figh menunjukkan bahwa ilmu tersebut tidak mandeg, melainkan berkembang secara dinamis. Ada beberapa aliran metode penulisan ushul fiqh yang saat ini dikenal. Secara umum, para ahli membagi aliran penulisan ushul fiqh menjadi dua, yaitu mutakallimin (Syafi'iyyah) dan aliran fukaha (Aliran Hanafiyah). Dari kedua aliran tersebut lahir aliran gabungan. Tiga aliran utama tersebut diuraikan sebagai berikut:

\section{Aliran Mutakallimin}

Aliran mutakallimin disebut juga dengan aliran Syafi'iyyah. Alasan penamaan tersebut bisa dipahami mengingat karya-karya ushul fiqh aliran mutakallimin banyak lahir dari kalangan Syafi'iyyah, seperti al-Luma' karya al-Syirazi, al-Mustashfa karya al-Ghazali, al-Mahsul karya Fakhruddin al-Razi, al-Burhan dan al-Waraqat karya al-Juwayni, al-Ihkam fi Ushul al-Ahkam karya al-Amidi, Minhaj al-Wushul ila Ilm a'-Ushul karya al-Baidlawi dan sebagainya. Karya al-Ghazali, al-Razi, dan al-Amidi banyak dirujuk oleh para ahli ushul fiqh dari madzhab non-Syafi'i. Kitab Rawdlah al-Nadzir wa Jannah al-Munadzir karya tokoh Hanabilah Ibnu Qudamah al-Maqdisi, misalnya, dipandang sebagai ringkasan dari alMustashfa karya al-Ghazali dan kitab Muntaha al-Wushul (al-Sul)wa alAmal fi Ilmay al-Ushul wa al-Jadal karya Ibnu Hajib dipandang sebagai ringkasan kitab al-Ihkam fi ushul al-Ahkam karya al-Amidi.. Meskipun demikian, penulis-penulis ushul fiqh model mutakallimin hanya orang Asy'ariyyah. Penulis ushul fiqh aliran mutakallimin bersifat lintas madzhab. Ada penulis dari kalangan Hanbali, seperti

1) Abu Ya’la (pengarang al-Uddah),

2) Ibnu Qudamah (pengarang Rawdlah al-Nadzir wa Jannah alMunadzir),

3) Keluarga Ibnu Taimiyyah: Majduddin, Taqi al-Din, dan Ibnu Taimiyyah beserta ayah dan kakeknya (karangan ketiganya tercakup dalam kitab al-Musawwadah),

4) Najm al-Din al-Thufi pengarang Mukhtashar al-Rawdlah dan Syarh Mukhtashar al-Rawdlah).

Ada penulis dari kalangan Maliki, seperti: Ibnu Hajib (pengarang Muntaha al-Wushul (al-Sul) wa al-Alam fi Ilmay al-Ushul wa al-Jadal).

Ada pula penulis dari kalangan Dzahiriyyah, seperti: Ibnu Hazm al-Andalusi (pengarang kitab al-Ihkam fi Ushul al-Ahkam). Sebutan mutakallimin adalah sesuai dengan karakteristik penulisannya. Kaum mutakallimin adalah orang-orang yang banyak bergulat dengan pembahasan teologis dan banyak memanfaatkan pemikiran deduktif, termasuk logika Yunani. Orang-orang seperti Qadli Abdul Jabbar adalah 
seorang teolog Mu'tazilah. Imam Abu al-Husayn al-Bashri pun termasuk dalam aliran Mu'tazilah. Sementara itu, Imam Abu Bakar al-Baqillani, yang menulis buku al-Taqrib wa al-Irsyad dan diringkas oleh Imam al-Juwayni, dipandang sebagai Syaikh al-Ushuliyyin. Imam al-Juwayni sendiri, Imam al-Ghazali, dan Fakhruddin al-Razi adalah di antara tokoh-tokoh besar Asy'ariyyah penulis ushul fiqh. Ada pula penulis yang tidak menunjukkan kejelasan afiliasi teologis, tetapi menulis dengan pola mutakallimin, seperti Imam Abu Ishaq al-Syirazi. (Imam al-Syirazi dikenal sebagai pengikut Syafi'i yang non-Asy'ariyyah dan menjadi rival Imam al-Juwayni dalam perdebatan (munadzarah) teologis. Lihat catatan mengenai perdebatan teologis Abu Ishaq al-Syirazi dan Al-Juwayni dalam George alMakdisi,1981: 154)

Ada beberapa ciri khas penulisan ushul figh aliran Mutakallimin, antara lain: Penggunaan deduksi di dalamnya. Ushul fiqh mutakallimin membahas kaidah-kaidah, baik disertai contoh maupun tidak. Kaidahkaidah itulah yang menjadi pilar untuk pengambilan hukum. Jadi, kaidah dibuat dahulu sebelum digunakan dalam istimbath. Kaidah-kaidah tersebut utamanya berisi kaidah kebahasaan.

Adanya pembahasan mengenai teori kalam dan teori pengetahuan, seperti terdapat dalam al-Luma karya al-Syirazi dan al-Ihkam karya al-Amidi. Teori kalam yang sering dibahas adalah tentang tahsin dan taqbih. Sementara itu, dalam pembahasan mengenai teori pengetahuan tersebut, dimasukkan pengertian ilmu dan terkadang dimasukkan pula muqaddimah mantiqiyyah (pengantar logika), sebagaimana terdapat dalam al-Mustashfa karya al-Ghazali, Rawdlah al-Nadzir karya Ibnu Qudamah, dan Muntaha al-Wushul (al-Sul) karya Ibnu Hajib.

Aliran mutakallimin mengembangkan gagasan-gagasan yang telah ada dalam kitab al-Risalah karya al-Syafi'i dengan berbagai penjelasan dan materi tambahan. Aliran ini banyak diikuti oleh para ulama dan menjadi aliran utama dalam ushul fiqh, serta bersifat lintas madzhab.

\section{Aliran Hanafiyah}

Aliran Hanafiyah atau aliran Fukaha adalah aliran yang diikuti oleh para ulama madzhab Hanafi. Madzhab Hanafi adalah madzhab yang sejak semula memiliki pengembangan metodologis yang baik. Hal itu dibuktikan dengan pengaruh perkembangan ilmu qawaid fiqh di kalangan Syafi'iyyah yang dipengaruhi oleh qawaid fiqh Hanafi. Karena itu, mereka mengembangkan sendiri model penulisan ushul fiqh yang khas madzhab Hanafi.

Ciri khas penulisan madzhab Hanafi adalah berangkat dari persoalan-persoalan hukum yang furu yang dibahas oleh para imam mereka, lalu membuat kesimpulan metodologis berdasarkan pemecahan 
hukum furu tersebut. Jadi, kaidah-kaidah dibuat secara induktif dari kasuskasus hukum. Kaidah-kaidah tersebut bisa berubah dengan munculnya kasus-kasus hukum yang menuntut pemecahan hukum yang lain. Karena itu, ushul fiqh Hanafi dipenuhi dengan persoalan hukum yang nyata.

Karya ushul fiqh di kalangan Hanafi cukup banyak dikenal dan dirujuk. Kitab-kitab ushul fiqh yang khas menunjukkan metode Hanafiyah antara lain: al-Fushul fi Ushul Fiqh karya Imam Abu Bakar al-Jashshash (Ushul al-Jashshash) sebagai pengantar Ahkam al-Quran. Taqwim alAdillah karya Imam Abu Zayd al-Dabbusi Kanz al-Wushul ila Ma'rifat alUshul karya Fakhr al-Islam al-Bazdawi. Ushul Figh karya Imam alSarakhsi (Ushul al-Syarakhsi)

\section{Aliran Gabungan}

Pada perkembangannya muncul tren untuk menggabungkan kitab ushul fiqh aliran mutakallimin dan Hanafiyah. Metode penulisan ushul fiqh aliran gabungan adalah dengan membumikan kaidah ke dalam realitas persoalan-persoalan fiqh. Persoalan hukum yang dibahas imam-imam madzhab diulas dan ditunjukkan kaidah yang menjadi sandarannya.

Karya-karya gabungan lahir dari kalangan Hanafi dan kemudian diikuti kalangan Syafi'iyyah. Dari kalangan Hanafi lahir kitab Badi' alNidzam al-jami‘ bayn Kitabay al-Bazdawi wa al-Ihkam yang merupakan gabungan antara kitab Ushul karya al-Bazdawi dan al-Ihkam karya alAmidi. Kitab tersebut ditulis oleh Mudzaffar al-Din Ahmad bin Ali alHanafi. Ada pula kitab Tanqih Ushul karya Shadr al-Syariah al-Hanafi. Kitab tersebut adalah ringkasan dari Kitab al-Mahshul karya Imam al-Razi, Muntaha al-Wushul (al-Sul) karya Imam Ibnu Hajib, dan Ushul alBazdawi. Kitab tersebut ia syarah sendiri dengan judul karya Shadr alSyari'ah al-Hanafi. Kemudian lahir kitab Syarh al-Tawdlih karya Sa'd alDin al-Taftazani al-Syafii dan Jam' al-Jawami' karya Taj al-Din al-Subki alSyafi'i.

Tiga aliran di atas adalah aliran utama dalam ushul fiqh. Sebenarnya ada pula yang memasukkan takhrij al-furu' 'ala al-ushul dan aliran khusus sebagai aliran lain dalam ushul fiqh. Aliran takhrij al-furu' 'ala al-ushul dipandang berwujud berdasarkan dua kitab yang secara jelas menyebut istilah tersebut, yaitu Kitab Takhrij al-Furu' 'Ala al-Ushul karya al-Isnawi al-Syafi'i dan Takhrij al-Furu' 'ala al-Ushul karya al-Zanjani alHanafi. Sementara itu, aliran khusus adalah aliran yang mengkaji satu pokok bahasan ushul fiqh tertentu secara panjang lebar, seperti mengenai mashlahah mursalah sebagaimana dilakukan oleh al-Syatibi dalam alMuwafaqat atau oleh Muhammad Thahir 'Asyur dalam Maqashid alSyariah. 


\section{PENUTUP}

Periodisasi perkembangan ushul fiqh di mulai sejak zaman Rasulullah SAW sumber hukum Islam hanya dua, yaitu Al-Quran dan Assunnah. Apabila suatu kasus terjadi, Nabi SAW menunggu turunnya wahyu yang menjelaskan hukum kasus tersebut. Apabila wahyu tidak turun, maka Rauslullah SAW menetapkan hukum kasus tersebut melalui sabdanya, yang kemudian dikenal dengan hadits atau sunnah. Perkembangan Ushul Figh pada masa sahabat Memang, semenjak masa sahabat telah timbul persoalan-persoalan baru yang menuntut ketetapan hukumnya. Untuk itu para sahabat berijtihad, mencari ketetapan hukumnya. Setelah wafat Rasulullah SAW sudah barang tentu berlakunya hasil ijtihad para sahabat pada masa ini, tidak lagi disahkan oleh Rasulullah SAW, sehingga dengan demikian semenjak masa sahabat ijtihad sudah merupakan sumber hukum. Perkembangan Ushul Fiqh pada masa tabi'in, tabi'it-tabi'in dan para imam mujtahid, di sekitar abad II dan III Hijriyah wilayah kekuasaan Islam telah menjadi semakin luas, sampai ke daerahdaerah yang dihuni oleh orang-orang yang bukan bangsa Arab atau tidak berbahasa Arab dan beragam pula situasi dan kondisinya serta adat istiadatnya. Banyak diantara para ulama yang bertebaran di daerah-daerah tersebut dan tidak sedikit penduduk daerah-daerah itu yang memeluk agama Islam. Dengan semakin tersebarnya agama Islam di kalangan penduduk dari berbagai daerah tersebut, menjadikan semakin banyak persoalan-persoalan hukum yang timbul. Yang tidak didapati ketetapan hukumnya dalam Alquran dan As-Sunnah. Untuk itu para ulama yang tinggal di berbagai daerah itu berijtihad mencari ketetapan hukumnya. 


\section{DAFTAR PUSTAKA}

Abdul Wahab Ibrahim Abu Sulaiman. Al-Fiker al-Usuli: Dirasah Tabliliyah Naqdiyah. Jeddah: Dar al-Syuruq. 1983.

Noel James Coulson. History of Islamic Law. Edinburgh: Edinburgh University Press. 1964.

Imam al-Syirazi dikenal sebagai pengikut Syafi'i yang non-Asy'ariyyah The Rise of Colledge: Institution of Learning in Islam and in The West.Edinburgh: Edinburgh University Press.

Kisah di atas berasal dari hadits yang diriwayatkan oleh Imam Abu Dawud dan al-Nasa'i daru Abu Sa'id al-Khudri.

Muhammad Said al-Khinn. Atsar al-Ikhtilaf fi al-Qawaid al-Ushuliyyah fi Ikhtialaf al-Fuqaha. Beirut: Muassassah al-Risalah. 1994.

Muhammad al-Khudlary. Tarikh Tasyri’ al-Islamy. Surabaya: dar Ihya’ alKutub al-'Arabiyyah.

Thaha Jabir Alwani. Source Methodology in Islamic Jurisprudence. Virginia: IIIT. 1994.

Najmuddin al-Thufi. Kitab al-Ta'yin fi Syarh al-Arbain. Beirut: Muassasah alRayyan. 1998.

Wael B. Hallaq. A History of Islamic Legal Theories, an Introduction to Sunni Ushul Fiqh. Cambridge: Cambridge University Press. 